\title{
Does the dry cow treatment with monensin controlled release capsule affect Parmigiano Reggiano cheese production?
}

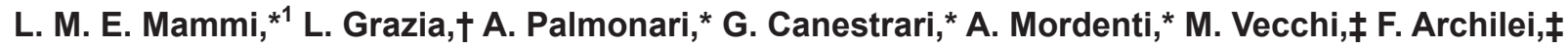 \\ and A. Formigoni* \\ *Department of Veterinary Medical Sciences, University of Bologna, 40064, Ozzano Emilia (Bo), Italy \\ †Department of Agricultural and Food Sciences, University of Bologna, 40127 Bologna, Italy \\ †Elanco Italia SpA, 50019 Sesto Fiorentino (FI), Italy
}

\section{ABSTRACT}

We investigated the effects of monensin controlledrelease capsule (CRC; Kexxtone, Eli Lilly and Company Ltd., Indianapolis, IN) preventative ketosis treatment on the traditional cheesemaking process as well as the final characteristics of Parmigiano Reggiano (PR) cheese. The use of this prevention product to reduce the incidence of ketosis in transition dairy cows was approved by the European Medicines Agency in 2013. No previous studies are available concerning the effects of this treatment on prolonged-ripening cheese production such as PR. In PR cheese production, feed, feed additives, and cow treatments are strictly regulated to avoid any possible interference with traditional manufacturing processes. For these reasons, on 1 farm where all milk was used for PR cheese production, monensin CRC was administered to 33 cows, $21 \mathrm{~d}$ before calving in the monensin-treated group (TRT), whereas untreated cows with similar breed and parity characteristics constituted the control group (CTR). For 20 wk, milk obtained from each group and whey starter were separately managed and transported in the cheese factory, where 2 cheese wheels per group were produced daily, making $552 \mathrm{PR}$ cheese wheels in total. Morning bulk tank milk composition, cheesemaking properties, and whey starter fermentation activities were analyzed twice a week. Every aspect of the cheesemaking process was recorded and the resulting cheese was evaluated after $36 \mathrm{~h}$ and 6,12 , and 18 mo from production for yield, texture defects, composition, and fatty acids profile. Milk from the 2 groups differed for somatic cell content $(\mathrm{TRT}=3.04$ vs. $\mathrm{CTR}=4.06$, somatic cell score), total bacterial count (TRT $=4.08$ vs. CTR $=6.08 \times 1,000 \mathrm{cfu} / \mathrm{mL})$, titratable acidity $(\mathrm{TRT}=$ 3.66 vs. CTR $=3.72$ Soxhlet-Henkel degrees $/ 50 \mathrm{~mL}$ ),

Received December 15, 2017.

Accepted June 13, 2018.

${ }^{1}$ Corresponding author: ludovica.mammi@unibo.it and casein content percentage $(\mathrm{TRT}=2.4$ vs. $\mathrm{CTR}$ $=2.5 \%$ ). Whey starter parameters were comparable between the 2 groups. Final cheese composition and organoleptic profile were not influenced by the treatment, except for C18:1 content being enhanced (TRT $=22.8$ vs. CTR $=20.8 \%$ of fatty acids). Percentage of defected ripened cheese was significantly lower in the treated group, both at x-ray evaluation performed at 6 mo $(\mathrm{TRT}=6.2$ vs. $\mathrm{CTR}=12.3 \%)$ and at the consortium inspection, performed at 12 mo of ripening (TRT $=1.5$ vs. $\mathrm{CTR}=6.5 \%$ ). On the other hand, average cheese yield at $18 \mathrm{mo}$ of ripening was partially reduced $(\mathrm{TRT}=7.5$ vs. $\mathrm{CTR}=7.7 \%)$. Overall, the use of monensin CRC had no negative effect on the cheesemaking process, prolonged ripening cheese characteristics, milk composition, or whey starter quality.

Key words: monensin, milk quality, Parmigiano Reggiano, cheese quality

\section{INTRODUCTION}

Ketosis is one of the most important diseases in modern herds due to its high incidence and its effects on cow health and performance. Recent studies reported that subclinical ketosis incidence within the first $16 \mathrm{~d}$ of lactation varies from 22 to $43 \%$ both in European and US herds (McArt et al., 2012; Suthar et al., 2013). Cows affected by subclinical or clinical ketosis have a higher risk of developing pathologies, such as displaced abomasum and metritis, as well as risk of culling as a consequence of health problems (Duffield et al., 2009; McArt et al., 2012; Suthar et al., 2013). Reproductive performance of these animals is often impaired and milk production reduced (McArt et al., 2015) together with changed composition. Indeed, ketosis reduces the protein content of milk on first DHI test day (Vanholder et al., 2015) and may consequently impair its cheesemaking properties.

In 2013, the European Medicines Agency approved a new treatment for prevention of ketosis in dairy cows: a 
monensin controlled-release capsule (CRC; Kexxtone, Eli Lilly and Company Ltd., Indianapolis, IN). Monensin is a carboxylic polyether ionophore commonly used as a feed additive in ruminants to alter rumen fermentation to improve energy efficiency (Russell and Strobel, 1989). Its effects on energy metabolism are well known and widely described both in beef and dairy cattle (Goodrich et al., 1984; Ipharraguerre and Clark, 2003; Duffield et al., 2012). Monensin has a selective action on rumen microbes: it alters ion exchange through the inner and outer membranes of microbial cells. In this way, it reduces the prevalence of protozoa and grampositive population and promotes gram-negative proliferation, which is mainly responsible for propionate production (Russell and Strobel, 1989). Therefore, the ratio between acetate and propionate changes in favor of propionate, thereby improving energy metabolism of cows (Russell and Strobel, 1989).

Monensin administration as a feed additive is not allowed in Europe; consequently, its introduction in 2013 as a ketosis-prevention product created a concern in the Italian dairy industry as to negative effects on the quality of cheese following production. In recent years, numerous studies have investigated the effects of monensin administration on animal metabolism and performance and regardless of whether or not it is administered as a feed additive or controlled-release capsule, the beneficial effects have included reduced nonesterified fatty acids and BHB plasma concentration, increased propionate production in the rumen, and decreased incidence of clinical and subclinical ketosis (Duffield et al., 1998). On the other hand, only a few studies have explored the effects on milk quality, and these have shown contrasting results. To our knowledge, no studies have assessed the effect of monensin on cheese quality. Mullins et al. (2012) did not find any changes in milk production and composition in monensin-treated cows, whereas other authors found a significant reduction in milk fat and protein content percentage (Odongo et al., 2007; Duffield et al., 2012).

Parmigiano Reggiano cheese is traditionally made with raw, unpasteurized and partially skim milk. To produce this kind of cheese, feedstuffs, management, and milk processing must be in compliance with Parmigiano Reggiano regulations (Consorzio del Formaggio Parmigiano Reggiano, 2011) by virtue of the Ministerial Decree in force since October 1, 2011, that implement the European regulation for Protected Designation of Origin production (European Council, 2006). Cows must be fed without silages; therefore, to maintain milk production and composition and to avoid ruminal disorders, a proper inclusion of high-quality hays in the ration is needed (Fustini et al., 2017).
In this specific manufacturing process, milk composition and environmental wild microflora are extremely important (Mordenti et al., 2017). Indeed, the microbial population of whey starter is fundamental for the quality and the maturation process of the cheese (Coloretti et al., 2016). Considering its antimicrobial activity, some have suggested that the administration of monensin might potentially impair cheese composition and quality. Therefore, the main purpose of our study was to evaluate the effect of a mass treatment of dry cows with monensin CRC on Parmigiano Reggiano cheese production.

\section{MATERIALS AND METHODS}

\section{Animals, Feeding, Management Conditions, and Treatment}

In the European Union, monensin use is restricted only to cows considered to be at high risk for ketosis. Consequently, the experimental design used in our study resulted in a more extreme scenario in which mass use of monensin CRC was required. This is typical of the summer heat stress period, when all cows are considered to be at high risk of ketosis. The treatment, monensin CRC (Kexxtone, Eli Lilly and Co. Ltd.), contained $32.4 \mathrm{~g}$ of monensin released continuously in the rumen throughout $95 \mathrm{~d}$, at a daily dose of $335 \mathrm{mg}$ (EMA, 2013).

Cows involved in the study were divided into 2 groups, treated (TRT) and control (CTR), and housed in 2 comparable, dedicated pens, with a straw-bedded resting area and cubicles. Thirty-three cows received the treatment $21 \mathrm{~d}$ before their expected calving date and gradually entered the TRT study group around 10 DIM, once milk became eligible for processing, according to Parmigiano Reggiano regulations (Consorzio del Formaggio Parmigiano Reggiano, 2011).

The percentage of cows in the TRT group within 95 $\mathrm{d}$ from treatment administration increased from $50 \%$ at the beginning of the trial to a maximum of $80 \%$ during wk 7 of the study. In the last 5 wk, the percentage of treated cows gradually decreased until 0 . The percentage of cows under treatment throughout the trial is shown in Figure 1.

All health problems were recorded as well as pharmaceutical treatments. Milk from cows treated with antimicrobials during the trial was not used for cheese manufacturing in the experimental groups for a period equal to double the standard withdrawal time to avoid any possible interference of the molecule on milk and whey starter quality. As soon as a cow exited the TRT group, new untreated cows entered to maintain a mini- 
mum of 29 to 30 cows per group and to have at least 1,000 to $1,100 \mathrm{~kg}$ of milk/d per group, sufficient to produce 2 cheese wheels a day from each group.

During the experiment, both groups received the same TMR, delivered twice a day. The ration was formulated according to Parmigiano Reggiano feeding rules (Consorzio del Formaggio Parmigiano Reggiano, 2011). Samples of TMR were collected monthly and analyzed using near infrared spectroscopy equipment for moisture, CP, starch, ash-corrected $\alpha$-amylase-treated NDF with addition of sodium sulfite (Mertens, 2002), ADF and ADL, fat, and ash after $4 \mathrm{~h}$ of combustion in a muffle furnace $550^{\circ} \mathrm{C}$ (Vulcan 3-550, Dentsply Neytech, Burlington, NJ). Ingredients and chemical composition of the diet are shown in Table 1.

\section{Milking and Cheese Production}

Cows of both groups were milked separately, twice a day, and milk was stored in separated tanks. Milk and whey starter obtained from the 2 experimental groups were maintained separately from each other and from the rest of the herd during every phase of the cheesemaking process using 2 different copper vats for the cooking procedure and 2 different comparable tanks for the storage of whey starter.

Each day, 2 cheese wheels per group were produced and marked following Parmigiano Reggiano cheese production standards (Consorzio del Formaggio Parmigiano Reggiano, 2011). Cheese wheels of both groups were stored together in the same traditional ripening rooms for 18 mo.

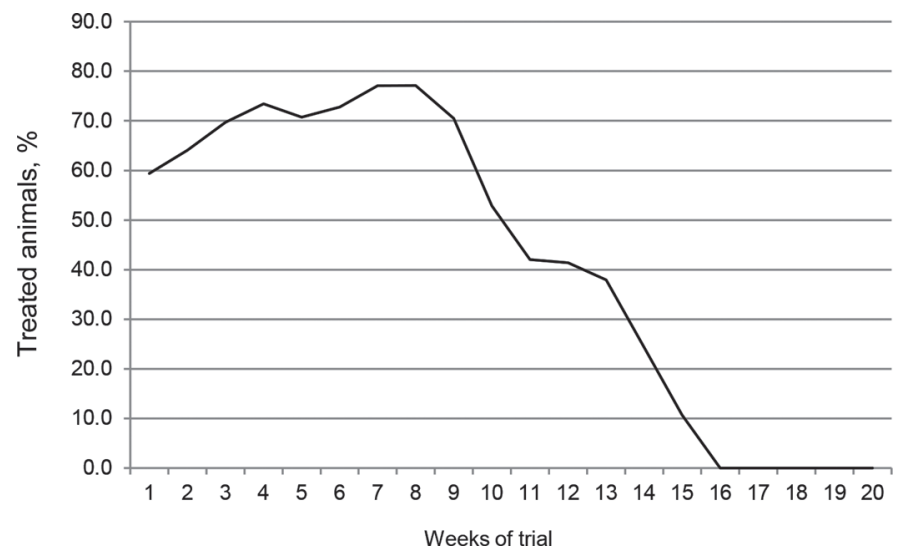

Figure 1. Percentage of animals in treated group within $95 \mathrm{~d}$ since treatment administration, from wk 1 to 20 of the trial. Treatment $=$ monensin controlled-release capsule, administered to cows $21 \mathrm{~d}$ before predicted calving date.

\section{Milk, Whey Starter, and Cheese Analysis}

Every day the amount of milk produced and delivered to the cheese factory by the 2 groups was recorded. Morning bulk tank milk and whey starter was collected on the same day, twice a week, for a total of 35 samples per group and analyzed by a qualified laboratory (Artest SpA, Modena, Italy). Milk samples were analyzed for fat, $\mathrm{CP}$, casein, total lactose, SCC, and urea content, total bacteria count (TBC), $\mathrm{pH}$, titratable acidity [Soxhlet-Henkel degrees $\left({ }^{\circ} \mathbf{S H}\right) / 50 \mathrm{~mL}$ ], and clotting time $\left(\mathrm{r}^{\prime}, \mathrm{min}\right)$ through lactodynamographic analysis (LDG). Milk components were measured by midinfrared analysis (Biggs, 1978) with a MilkoScan 6000 FT (Foss Electric, Hillerød, Denmark). Precalibration procedures were performed according to International Dairy Federation Standards 141C:2000 (IDF, 2000) using total nitrogen for protein expression. Urea content was determined by differential pH-metry with CL-10 Plus (BioControl Systems, Merck, Darmdstadt, Germany) according to ISO method 14637 (ISO, 2004c), and SCC and TBC by flow cytometry (SchmidtMadsen, 1975) with Combifoss and Bactoscan FC apparatus, respectively (Foss Electric), according to ISO method 13366-2 (ISO, 2006) and 16297 (ISO, 2013). Titratable acidity was determined by Soxhlet-Henkel method (Anonymous, 1963) and $\mathrm{pH}$ measurements using a potentiometric technique with a compact titrator equipped with electrode $\mathrm{P} / \mathrm{N} 5364$ (Crison Instruments, Barcelona, Spain). The $\mathrm{pH}$ was determined at

Table 1. Ingredients and chemical composition (\% DM, unless noted) of diets fed to lactating cows of treated ${ }^{1}$ and control groups

\begin{tabular}{lr}
\hline Item & $\%(\mathrm{DM})$ \\
\hline Ingredient & \\
Grass hay & 17.18 \\
Wheat straw & 3.44 \\
Alfalfa hay & 27.49 \\
Corn meal, fine & 3.44 \\
Sorghum meal, fine & 18.90 \\
Wheat meal, fine & 11.34 \\
Wheat bran & 7.56 \\
Protein supplement & 0.94 \\
Mineral and vitamin supplement & 0.94 \\
Chemical composition & \\
DM, \% & 77.77 \\
CP & 16.11 \\
Starch & 25.05 \\
aNDFom & 28.91 \\
ADF & 23.30 \\
ADL & 4.21 \\
Fat & 2.19 \\
Ash & 9.49 \\
\hline
\end{tabular}

${ }^{1}$ Treatment: monensin controlled-release capsule, administered to cows $21 \mathrm{~d}$ before predicted calving date.

${ }^{2}$ aNDFom: $\alpha$-amylase-treated NDF, ash corrected. 
samples temperature of $25^{\circ} \mathrm{C}$ after calibration of $\mathrm{pH}$ meter at the same temperature. Coagulation properties were assessed with a Formagraph apparatus (Foss Electric) under isothermal conditions at $35^{\circ} \mathrm{C}$ (Annibaldi et al., 1977).

Whey starter samples were analyzed for titratable acidity and fermentative activity at 45,52 , and $54^{\circ} \mathrm{C}$. Acidification rate at different temperatures was evaluated by inoculating $1.5 \mathrm{~mL}$ of whey in $50 \mathrm{~mL}$ of skim milk (Oxoid, Thermo Fisher Scientific Inc., Monza, Italy). The incubation was carried out at different temperatures $\left(45,52\right.$, and $\left.54^{\circ} \mathrm{C}\right)$ for $4 \mathrm{~h}$. The acidification rate at a specific temperature was expressed as the difference between the final and initial acidity $\left(\Delta^{\circ} \mathrm{SH} / 50\right.$ mL; Reverberi et al., 2009).

Total amount of lactic acid bacteria of whey starter was determined by dilution of the sample in physiological solution $(9 \mathrm{~g} / \mathrm{L}$ of $\mathrm{NaCl})$. Samples were then plated in de Man, Rogosa, Sharpe agar (Oxoid, Termo Fisher Scientific Inc.) and incubated anaerobically at $45^{\circ} \mathrm{C}$ for $96 \mathrm{~h}$ for thermophilic lactic acid bacteria quantification. The amount of whole and skim milk coming, respectively, from the milking of the morning and evening in the cooking vat was recorded daily by the cheesemaker and the ratio between them was evaluated.

All cheese wheels produced during the trial were evaluated over different time points during the maturation period. Cheeses were weighed $36 \mathrm{~h}$ and $18 \pm 1$ mo after production to assess cheese yield, calculated as kilograms of cheese $/ 100 \mathrm{~kg}$ of milk in the vat. For this purpose, all the milk added and cooked in each copper vat was measured by a magnetic flowmeter (Danfoss Magflow Flowmeter Type MAG 6000, Danfoss, Denmark) and recorded every day, together with the vat number and the code of the cheese wheels produced in that vat. At 6 mo of age, x-ray analysis of all cheese produced was performed by Artest SpA to identify internal defects such as swellings, splits, and eyes. Defects were classified as minor, mild, or severe based on their number and severity.

At 12 mo of ripening, experts of the Parmigiano Reggiano Consortium (Reggio Emilia, Italy) evaluated every cheese visually and by hammer-beating examination during the mandatory quality inspection as defined in the Consortium marking regulation (Consorzio del Formaggio Parmigiano Reggiano, 2011). Following this inspection, cheese wheels were classified into different categories depending on the presence of surface or texture defects, as prescribed in the Consortium marking regulation: first-quality cheese was cheese with minor defects, whereas second-quality cheese and rejected cheese cannot be marked as Parmigiano Reggiano cheese (Consorzio del Formaggio Parmigiano Reggiano, 2011).
At the end of the ripening period, $18 \pm 1 \mathrm{mo}$, a representative sample of first-quality cheese (24/group) were sampled according to IDF sampling procedure (Emmons, 2000) and evaluated for composition, fatty acid profile, and organoleptic analysis. Chemical analysis of cheese was performed by Artest SpA for the determination of moisture (5534; ISO, 2004b), fat (1735; ISO, 2004a), and protein content (8968-1; ISO, 2014), total and water-soluble nitrogen (27871; ISO, 2011), VFA, and ripening index $\left(\mathrm{N}_{\text {soluble }} / \mathrm{N}_{\text {total }} \times 100\right)$.

The amount of acetic, propionic, and butyric acids was assessed by HPLC analysis (UV detector, SUPELcogEL C-610H (Sigma-Aldrich, St. Louis, MO), $300 \times 7.8 \mathrm{~mm}$ column, mobile phase: $0.1 \%$ wt/vol phosphoric acid.). Fatty acid methyl esters were evaluated by the Animal Production and Food Safety laboratory of the Department of Veterinary Medical Sciences, University of Bologna, by capillary GC (Antongiovanni et al., 2007). Lipids extraction was performed by the Folch method (Folch et al., 1957), whereas acid-catalyzed transmethylation was performed according to the Stoffel method (Stoffel et al., 1959) to recover the free fatty acid component of ripened cheese (Liu, 1994).

Sensory analysis of cheese was performed by Research Center for Animal Production (Reggio Emilia, Italy) applying a quantitative descriptive analysis test to determine the complete sensory profile of cheese, considering view, olfaction, taste, aftertaste, and structure. The test was conducted according to EN ISO 13299 (EN ISO, 2010) by 12 selected and trained panelists (ISO, 1993, 1994). The evaluation was performed by each panelist on 2 replicates of each sample served at a fixed temperature of $16 \pm 2^{\circ} \mathrm{C}$ following a blind random order. Parameters evaluated are shown in Table 2. Each feature was evaluated using a graduated scale from 1 (absence of sensation) to 7 (highest intensity of sensation).

\section{Statistical Analysis}

Summary statistics including mean, standard deviation, minimum, and maximum values were calculated for all outcome parameters, stratified on treatment group. Plots of the distribution of the outcome variables, as well as Shapiro-Wilk test, were performed to determine normal distribution. Somatic cell count data were first transformed into linear SCS (Wiggans and Shook, 1987). One-way ANOVA with treatment as fixed effects were used when the outcome variable was approximately normally distributed. Results of x-ray analysis and Consortium evaluation were tested using Chi-squared test. For all analysis, level of significance was set for $P \leq 0.05$. 
Table 2. Cheese sensorial descriptors evaluated during a quantitative descriptive analysis test performed by a trained expert panel on control and treated ${ }^{1}$ cheese samples at $18 \pm 1$ mo of ripening

\begin{tabular}{ll}
\hline Descriptor & Attribute \\
\hline Visual & Color, color homogeneity, number of eyes/break, diameter, visual suitability \\
Aroma & Total intensity, butter smell, rind smell, vegetable smell, dried fruit smell, negative smells, flavor suitability \\
Taste & Sweet, salted, bitter, spicy, butter taste, rind taste, dried fruit taste, broth taste, nutmeg taste, negative flavors, suitability \\
Texture & taste \\
\hline
\end{tabular}

${ }^{1}$ Treatment: monensin controlled-release capsule, administered to cows $21 \mathrm{~d}$ before predicted calving date.

\section{RESULTS AND DISCUSSION}

\section{Milk Production}

Average daily milk production was $1,626.4 \pm 220.1 \mathrm{~kg}$ for the CTR group and 1,154.9 $\pm 64.5 \mathrm{~kg}$ for the TRT group. This difference was due to the different number of animals in the 2 groups present in the farm throughout the trial: $51.8 \pm 7.0$ cows in control group and 29.9 \pm 1.5 in treated group. This situation was required by the experimental design, which aimed to have the maximum concentration of cows in the treated group within $95 \mathrm{~d}$ after treatment administration $(80 \%)$ to highlight any possible effects on milk and cheese quality. In this way, control milk exceeded the capacity of the cooking vat; thus, after the sampling procedure for the analysis, part of the control milk was processed separately from the rest of the experimental milk.

Considering the number of cows in each group, average production per head was higher in TRT than CTR $(38.50 \pm 1.48$ vs. $31.37 \pm 1.47 \mathrm{~kg})$, but as the production performances were not considered among the objectives of the trial, the collection of these data were not included in the experimental design. Therefore, comparison of individual milk yield cannot be properly analyzed.

\section{Milk and Whey Starter Quality}

Results of milk analysis are reported in Table 3 . Overall, bulk tank milk quality did not differ between the groups except for SCS, titratable acidity, and casein content percentage. Fat content (\%) and coagulation time (LDG, $\mathrm{r}^{\prime}$ ) were not affected by the treatment. The effect of monensin on milk fat content is inconsistent in the published literature (Duffield et al., 2012). Some authors attribute the decrease in milk fat synthesis sometimes observed when using monensin to a reduction in acetic acid produced in the rumen as a consequence of monensin action on ruminal microflora (Ramanzin et al., 1997; Van der Werf et al., 1998; Phipps et al., 2000). Other authors have found no effect on milk composition (Mullins et al., 2012), whereas Rico et al. (2014) suggested that monensin could interact with dietary component, such as starch or PUFA, when fed at high levels. Thus, the absence of a monensin effect on milk fat observed in the current study could be related to the low dietary inclusion of starch, typical of rations fed in Parmigiano Reggiano area.

Clotting time (LDG, $\mathrm{r}^{\prime}$ ) of milk was not affected by the treatment, despite the differences between the 2 groups in casein content, titratable acidity, and SCS. These results agree with the only other study that considered cheesemaking properties of milk, as Piccioli Cappelli et al. (1996) evaluated the effects of monensin as a feed additive on coagulation properties of milk and found no effects on coagulation time $\left(\mathrm{r}^{\prime}\right)$, curd firmness, or curd firming time.

Despite differences shown in Table 3, titratable acidity and casein content percentage of milk of both groups remained within a good range of milk used for Parmigiano Reggiano production (Zannoni and Mora, 1993; Sandri et al., 2001; Malacarne et al., 2006). In a meta-analysis Duffield et al. (2008a) reported hetero-

Table 3. Morning bulk tank milk composition and quality of treated ${ }^{1}$ and control group, analyzed twice a week for a total amount of 35 samples per group

\begin{tabular}{lccc}
\hline Item & Control & Treated & SEM \\
\hline Fat, $\%$ & 3.45 & 3.45 & 0.02 \\
Casein, $\%$ & $2.51^{* * *}$ & $2.44^{* * *}$ & 0.01 \\
CP, $\%$ & 3.30 & 3.21 & 0.04 \\
Lactose ${ }^{2} \%$ & 4.78 & 4.79 & 0.03 \\
Urea, mg $/ 100 \mathrm{~mL}$ & 19.69 & 20.05 & 0.32 \\
SCS & $4.06^{* * *}$ & $3.40^{* * *}$ & 0.05 \\
Titratable acidity, ${ }^{\circ} \mathrm{SH}^{3} / 50 \mathrm{~mL}$ & $3.69^{* * *}$ & $3.61^{* * *}$ & 0.01 \\
pH $^{4}{ }^{2}{ }^{5} \mathrm{r}^{\prime}$ & 6.67 & 6.67 & 0.00 \\
TBG $^{6}{ }^{6} \times 1,000 \mathrm{cfu} / \mathrm{mL}$ & 17.67 & 17.27 & 0.23 \\
& 6.71 & 5.57 & 0.56 \\
\hline
\end{tabular}

${ }^{1}$ Treatment: monensin controlled-release capsule, administered to cows $21 \mathrm{~d}$ before predicted calving date.

${ }^{2}$ Expressed on anhydrous basis.

${ }^{3}$ Soxhlet-Henkel degrees.

${ }^{4}$ Sample temperature $25^{\circ} \mathrm{C}$.

${ }^{5}$ Clotting time $\left(\mathrm{r}^{\prime}, \mathrm{min}\right)$ evaluated through lactodynamographic analysis.

${ }^{6} \mathrm{TBC}=$ total bacterial count.

*** $P<0.001$. 
geneous results regarding protein content in different studies, with an overall prevalence of studies that reported a decrease in protein percentage and an increase in protein yield in cows treated with monensin.

In our study, the difference in milk protein percentage between the groups was not significant, whereas the reduction in casein content percentage was. Few previous studies evaluated the effects of monensin on casein content, and they did not show any variation (Gandra et al., 2010; Trevisi et al., 2015). At the same time, other studies reported a significant reduction in milk protein and fat percentage that was explained by dilution effects due to the increased milk production of monensin-treated cows (Phipps et al., 2000). Somatic cells were significantly lower in the treated group, and this difference could be related to a better health status of animals treated with monensin (Duffield et al., 2008b).

Results of whey starter quality are shown in Table 4. No important differences appeared in the activity of treated and control whey starter. The amount of lactic bacteria was not different between the groups and, indeed, the power of acidification of whey starter, here represented by fermentation activities, was not impaired. Fermentative activities are strictly related to the microbial population of whey starters and were not affected by the treatment, as demonstrated by the high values of acidification rate (Reverberi et al., 2009). Titratable acidity of the treated group was lower than the control, but always remained within the optimal range $\left(29-31.5{ }^{\circ} \mathrm{SH} / 50 \mathrm{~mL}\right)$ for Parmigiano Reggiano production (Reverberi et al., 2009; Gatti et al., 2014). These results are extremely important for the dairy industry as, to our knowledge, no previous studies have evaluated the effects of monensin on whey starter quality and activity.

\section{Cheese Production and Defects}

During the study, 552 cheese wheels were produced, corresponding to 2 twin cheese wheels per group per day. As reported in Table 5, the weight of twin cheese evaluated at $36 \mathrm{~h}$ and $18 \pm 1$ mo of ripening were significantly lower $(P<0.01)$ in TRT than CTR group (90.8 vs. $93.7 \mathrm{~kg}$ at $36 \mathrm{~h}$ and 79.3 vs. $82.0 \mathrm{~kg}$ at $18 \mathrm{mo}$ ).

Cheese yield (\%), calculated as kilograms of cheese obtained by $100 \mathrm{~kg}$ of milk in the vat, showed the same difference both at $36 \mathrm{~h}$ (TRT $=8.6$ vs. CTR $=8.9 \%$, $P<0.05$ ) and after 18 mo of ripening (TRT $=7.5$ vs. CTR $=7.7 \%, P<0.01$ ). The lower cheese yield of treated group milk could be related to its lower casein content. Cheese yield and casein content of milk are directly proportional (Fossa et al., 1994). Formaggioni et al. (2015) proposed a simple predictive formula for Parmigiano Reggiano cheese yield at $24 \mathrm{~h}$, including only milk fat and casein content, that has a high correlation with the actual cheese yield (Formaggioni et al., 2015).

No early swelling, detectable within 24 to $8 \mathrm{~h}$ from production, was evident and both the experimental groups showed a very low percentage of defective cheese at 6 and 12 mo of ripening (Table 6). At x-ray analysis, performed on all cheese at 6 mo of ripening, $94 \%$ of cheese wheels in the TRT group showed no defects versus $88 \%$ of those in the CTR group. Overall, the TRT group showed less $(P<0.05)$ minor $($ TRT $=6.2$ vs. $\mathrm{CTR}=9.4 \%)$, mild $(\mathrm{TRT}=0$ vs. $\mathrm{CTR}=0.4 \%)$, and severe $(\mathrm{TRT}=0$ vs. $\mathrm{CTR}=2.5 \%)$ defects than the control group. X-ray analysis has been demonstrated to be a useful nondestructive method to monitor the development of individual cheese during the ripening period (Kraggerud et al., 2009).

Similar results were obtained during the subsequent examination of cheese, performed at 12 mo of ripening by the Consortium of Parmigiano Reggiano. The $98.6 \%$ of cheese produced by TRT group showed no defects and was marked as first-quality cheese compared with $93.5 \%$ in the CTR group. In the TRT group, $1.4 \%$ of wheels were marked as second quality and none of them were rejected, whereas in the CTR group $5.4 \%$ were second-quality cheese and $1.1 \%$ were rejected (Table 6 ). At official Consortium evaluation, defective cheeses in

Table 4. Whey starter quality of treated ${ }^{1}$ and control group, analyzed twice a week for a total amount of 35 samples per group

\begin{tabular}{|c|c|c|c|}
\hline Item & Control & Treated & SEM \\
\hline Titratable acidity, ${ }^{\circ} \mathrm{SH}^{2} / 50 \mathrm{~mL}$ & $30.43^{*}$ & $29.44^{*}$ & 0.23 \\
\hline Fermentative activity $45^{\circ} \mathrm{C},\left(\Delta^{\circ} \mathrm{SH} / 50 \mathrm{~mL}\right)$ & 2.51 & 2.67 & 0.08 \\
\hline Fermentative activity $52^{\circ} \mathrm{C},\left(\Delta^{\circ} \mathrm{SH} / 50 \mathrm{~mL}\right)$ & 1.93 & 1.97 & 0.05 \\
\hline Fermentative activity $54^{\circ} \mathrm{C},\left(\Delta^{\circ} \mathrm{SH} / 50 \mathrm{~mL}\right)$ & 1.47 & 1.46 & 0.03 \\
\hline Lactic bacteria, $\times 1$ million $\mathrm{cfu} / \mathrm{mL}$ & 660.57 & 613.43 & 14.19 \\
\hline
\end{tabular}


Table 5. Weight, cheese yield, composition, and VFA content (acetic, butyric, and propionic) of cheese produced by control and treated ${ }^{1}$ milk, analyzed at $18 \pm 1$ mo of ripening by an accredited laboratory for Parmigiano Reggiano analysis (Artest S.p.A., Modena, Italy)

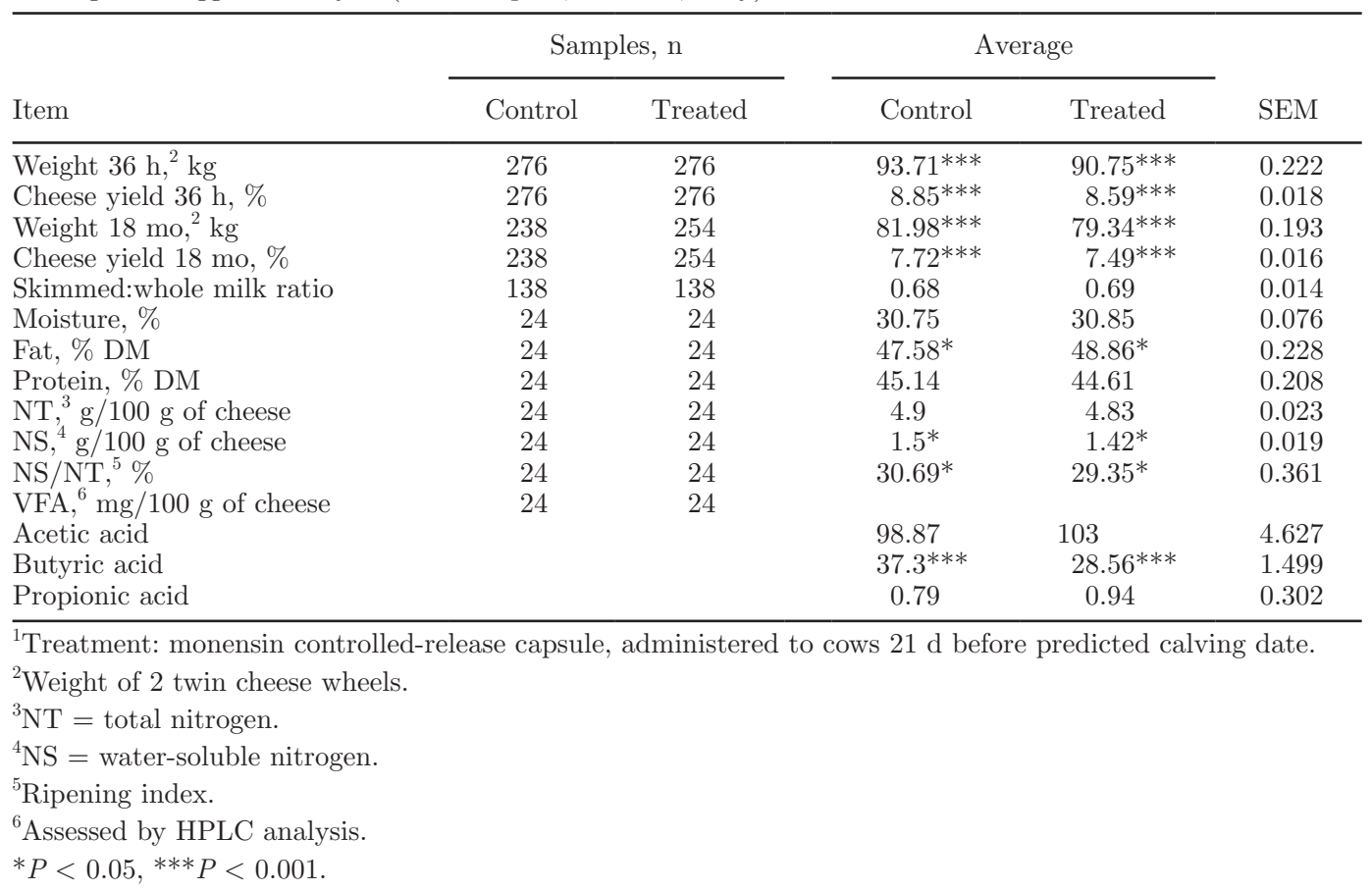

both groups were less than those recorded by the Consortium of Parmigiano Reggiano in the last 3 yr (20152017) of production: $91.5 \%$ of first-quality cheese, $7 \%$ of second-quality cheese, and $1.5 \%$ of rejected cheese (unpublished data, M. Nocetti, Consortium of Parmigiano Reggiano, Reggio Emilia, Italy).

Early swelling occurs rapidly after cheese production and is due to the proliferation of gas-producing bacteria within the cheese, coliform or heterofermentative lactic acid bacteria, and, more rarely, yeasts (Walstra et al., 1978). In particular, these defects become serious in the presence of large microbial populations $\left(10^{5}-10^{6}\right.$ per
$\mathrm{mL}$ ) and insufficient or slow acidification of milk that may occur as a consequence of a poorly active whey starter, presence of antibiotics, or contamination with phages. To avoid these abnormal fermentations and to assure a good ripening process, an active and proper microbial population of whey starter is fundamental (Bergère and Lenoir, 2000).

\section{Cheese Composition and Sensory Analysis}

After $18 \pm 1$ mo of ripening, cheese produced by the 2 groups differed for 2 characteristics: fat percentage

Table 6. Evaluation of cheese produced by treated ${ }^{1}$ and control group, performed after 6 mo of ripening by $\mathrm{x}$-ray and after 12 mo by visual and beating hammer (official examination by the Consortium of Parmigiano Reggiano, Reggio Emilia, Italy)

\begin{tabular}{lccc}
\hline Item & Control & Treated & $\chi^{2}$ \\
\hline Cheese, $\mathrm{n}$ & 276 & 276 & \\
X-ray analysis (6 mo), $\%$ & & & \\
No defects & $87.7^{*}$ & $93.8^{*}$ & 0.59 \\
Minor defects & $9.4^{*}$ & $0.2^{*}$ & 0.33 \\
Mild defects & $2.5^{*}$ & $0.0^{*}$ & 0.48 \\
Severe defects & & $0.0^{*}$ & 0.06 \\
Consortium evaluation (12 mo), $\%$ & $93.5^{*}$ & $98.6^{*}$ & 0.67 \\
First quality & $5.4^{*}$ & $1.4^{*}$ & 0.07 \\
Medium quality & $1.1^{*}$ & $0^{*}$ & 0.22 \\
Rejected
\end{tabular}

${ }^{1}$ Treatment: monensin controlled-release capsule, administered to cows $21 \mathrm{~d}$ before predicted calving date.

$* P<0.05$ 
was higher in treated cheese $(\mathrm{TRT}=48.86$ vs. $\mathrm{CTR}=$ $47.58 \%, P<0.05)$, whereas soluble nitrogen (TRT $=$ 1.42 vs. $\mathrm{CTR}=1.50 \mathrm{~g} / 100 \mathrm{mg}, P<0.05)$ and ripening index were lower $($ TRT $=29.35$ vs. $\mathrm{CTR}=30.69 \%, P$ $<0.05)$. Complete results are shown in Table 5.

Cheese fat and protein content of both groups differed from the average values expected in 18-mo aged Parmigiano Reggiano cheese, with fat content higher than protein content. In a survey by Tosi et al. (2008), the authors reported that the $40.5 \%$ of analyzed cheese had a fat content percentage higher than $44 \%$, with an average of $45.28 \%$ on a DM basis and a standard deviation of 0.95 . In the cited work, considering a normal distribution of this specific data subset, $95 \%$ of the samples had up to $47 \%$ of fat on DM basis, whereas $99 \%$ of samples reached the $48 \%$ of DM. These data are consistent with those observed in the current study and represents the actual trend of cheesemakers to produce a more fatty cheese to obtain higher cheese yields. Indeed, to correct this trend, in March 2018 the Consortium of Parmigiano Reggiano released a new version of the Official Regulation (Consorzio del Formaggio Parmigiano Reggiano 2018; by virtue of the Ministerial Decree in force as of May 9, 2018), in which the fat-to-protein ratio in vat milk has been fixed to a maximum value of 1.1. In the previous version (Consorzio del Formaggio Parmigiano Reggiano, 2011), no reference values for fat and protein content of cheese were included, except for the minimum value of fat $(32 \%$ of $\mathrm{DM})$.

The ripening index $\left(\mathrm{N}_{\text {soluble }} / \mathrm{N}_{\text {total }}, \%\right)$ represents the amount of casein solubilized by proteolytic enzymes during the ripening process (Tosi et al., 2008). The entity of proteolysis is driven by several environmental and technological factors, including duration of ripening, season, and the presence of catalytic enzymes in milk and starters used in the cheesemaking process (Addeo et al., 1988; Sousa et al., 2001). Plasmin and other proteases derived from somatic cells in milk and lactic bacteria present in the whey starter are the most effective in Parmigiano Reggiano proteolysis (Sousa et al., 2001). In the present study, environmental factors and the amount of lactic bacteria of whey starter were equal between the treatments; thus, the lower amount of soluble $\mathrm{N}$ of TRT cheeses could be explained by the lower SCC present in milk produced by treated cows (Table 3).

As shown in Table 5, acetic and propionic acids were not different between the groups. Unwanted bacteria produce propionic acid during the aging process, and its presence is responsible for texture defects of cheese and undesirable flavors (Bergère and Lenoir, 2000). Likewise, butyric acid-producing clostridia are responsible for off-flavors and cheese defects. Their capability to convert lactate into butyrate, acetate, $\mathrm{H}_{2}$, and $\mathrm{CO}_{2}$ can lead to the accumulation of gas in the cheese matrices that results in the formation of cracks, slits, and eyes (Sheehan, 2011; Brändle et al., 2016). During the ripening process, butyric acid is mainly produced by lipolysis facilitated by lipase present in cheese (Brändle et al., 2016). In our study, its amount was significantly lower $(P<0.001)$ in TRT than in CTR cheese, but its value remained within the values typical of 18 mo aged Parmigiano Reggiano cheeses for both groups (Table 5; Tosi et al., 2008).

These differences agree with the results of sensory analysis, which showed an overall comparable profile between cheeses with a few exceptions, shown in Table 7 and Figure 2. The TRT cheese samples, compared with CTR, showed a slower ripening process indicated by higher intensity of butter and sweet aroma [3.2 vs. $3.0(P<0.01)$ and 3.5 vs 3.4 points $(P<0.05)]$, lower rind and spicy flavors $[2.0$ vs $2.1(P<0.05)$ and 1.8 vs. 1.9 points $(P<0.05)]$, and higher elasticity $(2.5$ vs. 2.4 points, $P<0.05)$. In addition, TRT cheeses had a less intense, negative aroma, such as pungent, acetic, and stall, than CTR cheeses $(2.1$ vs. 2.2 points, $P<0.05)$

However, it should be noted that these differences did not influence the overall sensory profile of cheese of both groups, which were comparable with organoleptic characteristics of 18-mo aged Parmigiano Reggiano cheese (Garavaldi et al., 2010), and in compliance with those required by the official certification body of Parmigiano Reggiano (OCQPR, 2015). Cheese fatty acids (FA) profile is shown in Table 8.

In the TRT group, the percentage of medium-chain FA (C10 to C14) on total FA was reduced (TRT $=20.22$ vs. $\mathrm{CTR}=21.73, P<0.05)$, whereas among long-chain fatty acids both $\mathrm{C} 18: 1(\mathrm{TRT}=22.77$ vs. CTR $=20.79$, $P<0.001)$ and $\mathrm{C}: 17(\mathrm{TRT}=0.66$ vs. $\mathrm{CTR}=0.61, P$ $<0.05)$ were increased. Along with this, UFA and SFA

Table 7. Cheese sensorial descriptors significantly different between treated $^{1}$ and control group, evaluated by quantitative descriptive analysis test performed by a trained expert panel on $18 \pm 1$ mo cheese samples (samples $\mathrm{n}=24+24$; complete sensory profile is shown in Figure 2)

\begin{tabular}{lccc}
\hline Item & Control & Treated & SEM \\
\hline Butter & $3.0^{* *}$ & $3.2^{* *}$ & 0.06 \\
Rind & $2.1^{*}$ & $2.0^{*}$ & 0.06 \\
Sweet & $3.4^{*}$ & $3.5^{*}$ & 0.05 \\
Spicy & $1.9^{*}$ & $1.8^{*}$ & 0.06 \\
Others $^{2}$ & $2.2^{*}$ & $2.1^{*}$ & 0.06 \\
Elasticity & $2.4^{*}$ & $2.5^{*}$ & 0.07 \\
\hline
\end{tabular}

${ }^{1}$ Treatment: monensin controlled-release capsule, administered to cows $21 \mathrm{~d}$ before predicted calving date.

${ }^{2}$ Negative aroma, such as pungent, acetic, and stall.

${ }^{*} P<0.05,{ }^{* *} P<0.01$. 


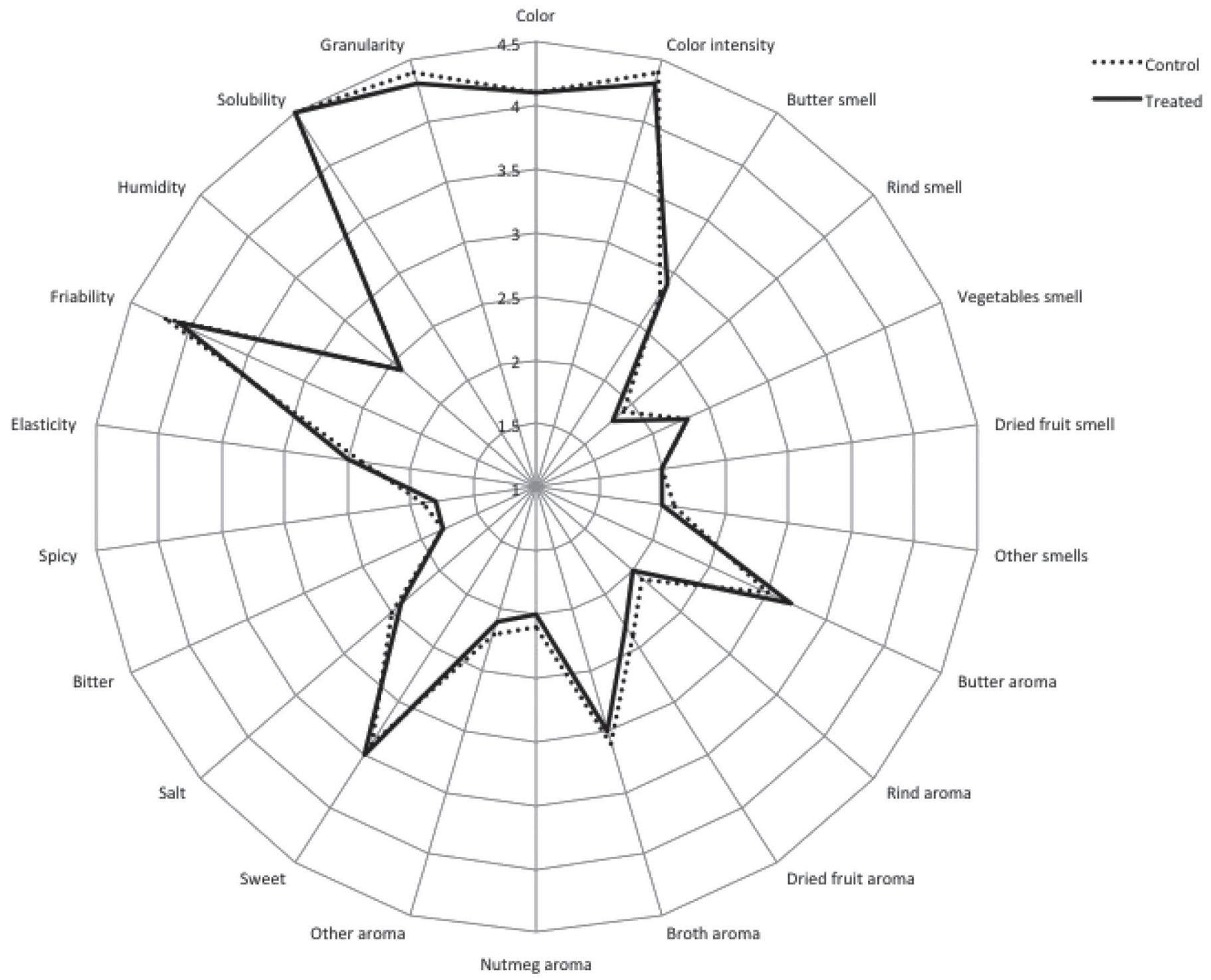

Figure 2. Sensory profile of $18 \pm 1$ mo aged cheese produced by treated and control group evaluated by quantitative descriptive analysis test performed by a trained expert panel (samples, $\mathrm{n}=24+24$ ). Treatment $=$ monensin controlled-release capsule, administered to cows $21 \mathrm{~d}$ before predicted calving date.

ratios were increased in the treated group $(\mathrm{TRT}=0.42$ vs. $\mathrm{CTR}=0.39, P<0.05)$. Regardless of treatment or control, cheese fatty acid composition of all samples were in agreement with those reported by other authors for Parmigiano Reggiano cheese (Prandini et al., 2007; Mordenti et al., 2015).

Even if no other studies, to our knowledge, evaluated the effects of monensin on cheese FA concentration, our results correspond with literature evaluating FA variations in milk produced by cows treated with monensin sodium when administered as a feed additive or as CRC (Duffield et al., 2008a; De Marchi et al., 2015). It has to be noted that the FA composition of milk is influenced also by the stage of lactation of cows. In our study, DIM of the experimental groups were not controlled; therefore, it is possible that at least some of the difference in FA profile of cheese between the groups could be due to the presence of a higher percentage of fresh cows in the treated group. Existing literature, however, supports the theory that monensin influences FA concentration in milk by altering ruminal microbiota (Bell et al., 2006; McCarthy et al., 2018).

Odongo et al. (2007) showed an increased concentration of long-chain PUFA and total MUFA in milk by 9 and $5 \%$, respectively, in a group fed TMR +24 $\mathrm{mg}$ of monensin premix per kilogram of DM compared 
with a control group. Other studies, as reported by Duffield et al. (2008b), showed the same increase in total C18:1 and PUFA concentrations, a reduction of short and medium-chain fatty acids, and a reduction of PUFA-to-SFA ratio (AlZahal et al., 2008; De Marchi et al., 2015). The same effects were observed by in vitro studies, which reported a decrease of C18:2 ruminal biohydrogenation by lowering $\mathrm{C} 18: 0$ production and increasing C18:1 concentration (Fellner et al., 1997; Jenkins et al., 2003).

In addition, an increase of CLA has been reported after monensin supplementation (Duffield et al., 2008a), whereas in our study CLA concentration remained similar between the groups $(\mathrm{TRT}=0.36$ vs. CTR $=$ $0.35, P>0.05)$. On the contrary, only a few recent studies have reported no (Do Prado et al., 2015) or minimal (Akins et al., 2014) effects of monensin on milk FA composition.

The rate of ruminal biohydrogenation of UFA depends primarily on ruminal conditions, including microbial growth, rumen $\mathrm{pH}$, and feed passage rate. Low rumen $\mathrm{pH}$ and altered microbial growth contribute to reduce rumen lipolysis, and therefore the availability of carboxyl groups for the biohydrogenation of UFA (Jenkins, 1993). Indeed, ionophores reduce rumen lipolysis, as do other antimicrobial compounds known

Table 8. Fatty acid composition (\% of fatty acids) of $18 \pm 1$ mo aged cheese produced with control and treated ${ }^{1}$ milk (samples $\mathrm{n}=24+24$ )

\begin{tabular}{lccl}
\hline Fatty acid & Control & Treated & SEM \\
\hline C4:0 & 3.35 & 3.6 & 0.291 \\
C6:0 & 1.51 & 1.44 & 0.118 \\
C8:0 & 1.28 & 1.19 & 0.056 \\
C10:0 & $3.59^{*}$ & $3.31^{*}$ & 0.095 \\
C10:1 & $0.3^{* *}$ & $0.25^{* *}$ & 0.009 \\
C12:0 & $4.23^{* *}$ & $3.79^{* *}$ & 0.087 \\
C12:1 & $0.12^{* *}$ & $0.1^{* *}$ & 0.004 \\
C14:0 & $12.34^{*}$ & $11.77^{*}$ & 0.164 \\
C14:1 & $1.15^{* * *}$ & $1^{* * *}$ & 0.018 \\
C15:0 & 1.52 & 1.45 & 0.032 \\
C16:0 & 34.44 & 34.07 & 0.288 \\
C16:1 & 1.47 & 1.4 & 0.08 \\
C17:0 & $0.61^{*}$ & $0.66^{*}$ & 0.015 \\
C18:0 & 6.84 & 6.97 & 0.155 \\
C18:1 & $20.79^{* * *}$ & $22.77^{* * *}$ & 0.316 \\
C18:2 & 2.14 & 2.16 & 0.056 \\
C18:3 n-3 & 0.54 & 0.5 & 0.02 \\
C20:0 & 0.08 & 0.07 & 0.007 \\
C20:4 n-6 & 0.14 & 0.12 & 0.007 \\
CLA total & 0.35 & 0.36 & 0.014 \\
Others & 3.21 & 3.02 & 0.254 \\
\hline
\end{tabular}

${ }^{1}$ Treatment: monensin controlled-release capsule, administered to cows $21 \mathrm{~d}$ before predicted calving date.

${ }^{2}$ Nonidentified fatty acids.

${ }^{*} P<0.05,{ }^{* *} P<0.01,{ }^{* * *} P<0.001$. to be active mainly against gram-positive bacteria (Russell and Strobel, 1989; Van Nevel and Demeyer, 1995). However, as reported by Fellner et al. (1997), these bacteria are not involved in rumen lipolysis or in the last step of biohydrogenation of linoleic to stearic acid. For this reason, it seems to be possible that these molecules exert their effects also against gram-negative bacteria by changing their metabolic properties, with a consequent alteration of rumen lipolysis and biohydrogenation (Newbold et al., 1993; Odongo et al., 2007).

\section{CONCLUSIONS}

Milk and whey starter produced during the trial were not affected by the treatment of cows with monensin CRC; the differences found in titratable acidity and casein content of milk and in titratable acidity of whey starter agree with the existing literature that relates these effects to the higher milk production of monensintreated cows. However, both milk and whey starter maintained the optimum quality for Parmigiano Reggiano cheese production. In particular, fermentative activities of whey starter were not impaired in the treated group at 45 or $54^{\circ} \mathrm{C}$. This was one of the major initial concerns, considering the absence of published studies and the importance of whey starter for Parmigiano Reggiano production, in which the use of any other kind of fermentation is not allowed. After ripening, the percentage of defective cheeses in both groups was consistent with values reported by the Consortium of Parmigiano Reggiano for the last 3 yr. Additionally, the TRT cheeses showed less defects than controls. Chemical analysis did not highlight any negative influence of the treatment on composition and fatty acid profile. Sensory analysis demonstrated that the treatment did not substantially affect organoleptic characteristics of 18-mo aged Parmigiano Reggiano cheese. In conclusion, high-quality cheese production was maintained in both the control and treated groups and, considering our results, it is possible to state that the preventative treatment of ketosis with monensin CRC of periparturient dry cows did not impair Parmigiano Reggiano cheese quality, composition, and sensory characteristics.

\section{ACKNOWLEDGMENTS}

The authors express their appreciation to the F.lli Caretti dairy farm and cheese factory team (San Giovanni in Persiceto, Italy) for their involvement in the trial and to Andrea Summer (University of Parma, Italy) and Marco Nocetti (Consortium of Parmigiano Reggiano, Reggio Emilia, Italy) for their contribution. 
In addition, we thank Elanco Animal Health for funding the study.

\section{REFERENCES}

Addeo, F., L. Moio, and C. Stingo. 1988. Typical characteristics of proteolysis in Parmigiano-Reggiano cheese. Pages 21-40 in Triennial Research on the Composition and the Peculiar Characteristics of Parmigiano-Reggiano Cheese. Consorzio Parmigiao Reggiano, Reggio Emilia, Italy.

Akins, M. S., K. L. Perfield, H. B. Green, S. J. Bertics, and R. D. Shaver. 2014. Effect of monensin in lactating dairy cow diets at 2 starch concentrations. J. Dairy Sci. 97:917-929. https://doi.org/10 .3168/jds.2013-6756.

AlZahal, O., N. E. Odongo, T. Mutsvangwa, M. M. Or-Rashid, T. F. Duffield, R. Bagg, P. Dick, G. Vessie, and B. W. McBride. 2008. Effects of monensin and dietary soybean oil on milk fat percentage and milk fatty acid profile in lactating dairy cows. J. Dairy Sci. 91:1166-1174. https://doi.org/10.3168/jds.2007-0232.

Annibaldi, S., G. Ferri, and R. Mora. 1977. Nuovo orientamenti nella valutazione tecnica del latte: Tipizzazione lattodinamografica. Sci. Tecn. Latt. Cas. 28:115-126. (New trends for milk technical evaluation: Lactodynamographic standardisation).

Anonymous. 1963. Säuregradbestimmung nach Soxhlet-Henkel (SH) [Titratable acidity evaluation with the Soxhlet-Henkel (SH) method]. Milchwissenschaft 18:520.

Antongiovanni, M., S. Banni, A. Buccioni, L. Cercaci, G. Contarini, M. Cutrignelli, G. Lercker, D. Lo Fiego, M. Mele, S. Minieri, A. Nudda, E. Piasentier, and A. Serra. 2007. Metodi Di Analisi per Lo Studio Della Frazione Lipidica Del Latte, Dei Prodotti Di Origine Animale e Degli Alimenti Zootecnici. Plus Pisa University Press, Pisa, Italy.

Bell, J. A., J. M. Griinari, and J. J. Kennelly. 2006. Effect of safflower oil, flaxseed oil, monensin, and vitamin $\mathrm{E}$ on concentration of conjugated linoleic acid in bovine milk fat. J. Dairy Sci. 89:733-748.

Bergère, J. L., and J. Lenoir. 2000. Cheese Manufacturing Accidents and Cheese Defects. Lavoisier Publishing, Paris, France.

Biggs, D. A. 1978. Instrumental infrared estimation of fat, protein, and lactose in milk: collaborative study. J. Assoc. Off. Anal. Chem. 61:1015-1034.

Brändle, J., K. J. Domig, and W. Kneifel. 2016. Relevance and analysis of butyric acid producing clostridia in milk and cheese. Food Control 67:96-113. https://doi.org/10.1016/j.foodcont.2016.02 .038 .

Coloretti, F., C. Chiavari, M. Nocetti, P. Reverberi, E. Bortolazzo, V. Musi, and L. Grazia. 2016. Whey starter addition during maturation of evening milk: effects on some characteristics of cheese milk and Parmigiano-Reggiano cheese. Dairy Sci. Technol. 96:185-197.

Consorzio del Formaggio Parmigiano Reggiano. 2011. Specification of the Parmigiano Reggiano cheese. Accessed Oct. 24 2017. http:/ /www.parmigianoreggiano.com/consortium/rules_regulation_2/ default.aspx.

Consorzio del Formaggio Parmigiano Reggiano. 2018. Specification of the Parmigiano Reggiano cheese. Accessed May 2018. https: //www.parmigianoreggiano.it/consorzio/disciplinare_produzione _vigente_30_03_2018/default.aspx.

De Marchi, F. E., J. V. Romero, J. C. Damasceno, P. A. Grande, L. M. Zeoula, and S. Dos. 2015. Pelleting in associated with sodium monensin increases the conjugated linoleic acids concentration in the milk of dairy cows fed canola seeds. Asian-australas. J. Anim. Sci. 28:1095-1104. https://doi.org/10.5713/ajas.14.0865.

Do Prado, R. M., C. Côrtes, C. Benchaar, and H. V. Petit. 2015. Interaction of sunflower oil with monensin on milk composition, milk fatty acid profile, digestion, and ruminal fermentation in dairy cows. Anim. Feed Sci. Technol. 207:85-92. https://doi.org/ 10.1016/j.anifeedsci.2015.06.017.

Duffield, T. F., K. D. Lissemore, B. W. McBride, and K. E. Leslie. 2009. Impact of hyperketonemia in early lactation dairy cows on health and production. J. Dairy Sci. 92:571-580. https://doi.org/ 10.3168/jds.2008-1507.

Duffield, T. F., A. Rabiee, and I. J. Lean. 2012. Overview of metaanalysis of monensin in dairy cattle. Vet. Clin. North Am. Food Anim. Pract. 28:107-119. https://doi.org/10.1016/j.cvfa.2011.12 .009 .

Duffield, T. F., A. R. Rabiee, and I. J. Lean. 2008a. A meta-analysis of the impact of monensin in lactating dairy cattle. Part 2. Production effects. J. Dairy Sci. 91:1347-1360. https://doi.org/10.3168/ jds.2007-0608.

Duffield, T. F., A. R. Rabiee, and I. J. Lean. 2008b. A meta-analysis of the impact of monensin in lactating dairy cattle. Part 3. Health and reproduction. J. Dairy Sci. 91:2328-2341. https://doi.org/10 .3168/jds.2007-0801.

Duffield, T. F., D. Sandals, K. E. Leslie, K. Lissemore, B. W. McBride, J. H. Lumsden, P. Dick, and R. Bagg. 1998. Efficacy of monensin for the prevention of subclinical ketosis in lactating dairy cows. J. Dairy Sci. 81:2866-2873.

EMA. 2013. European Public Assessment Reports (EPAR) European Medicine Agency. Accessed January 2018 http://www.ema.europa .eu/ema/index.jsp?curl=pages/medicines/veterinary/medicines $/$ 002235/vet_med_000267.jsp\&mid=WC0b01ac058001fa1c

Emmons, D. B. 2000. Sampling and analysis. Pages 74-86 in: Practical Guide for Control of Cheese Yield. International Dairy Federation, Brussels, Belgium.

EN ISO. 2010. Sensory analysis. Methodology. General guidance for establishing a sensory profile. EN ISO 13299. European Committee for Standardization. Brussels, Belgium.

European Council. 2006. Council Regulation (EC) No 510/2006 of 20 March 2006 on the protection of geographical indications and designations of origin for agricultural products and foodstuffs. Official Journal of the European Union. 49:12-25. Accessed Oct. 2017. http://eur-lex.europa.eu/eli/reg/2006/510/oj

Fellner, V., F. D. Sauer, and J. K. Kramer. 1997. Effect of Nigericin, Monensin, and Tetronasin on biohydrogenation in continuous flowthrough ruminal fermenters. J. Dairy Sci. 80:921-928.

Folch, J., M. Lees, and G. H. Sloane Stanley. 1957. A simple method for the isolation and purification of total lipids from animal tissues. J. Biol. Chem. 226:497-509.

Formaggioni, P., A. Summer, M. Malacarne, P. Franceschi, and G. Mucchetti. 2015. Italian and Italian-style hard cooked cheeses: Predictive formulas for Parmigiano-Reggiano 24-h cheese yield. Int. Dairy J. 51:52-58. https://doi.org/10.1016/j.idairyj.2015.07 .008 .

Fossa, E., M. Pecorari, S. Sandri, F. Tosi, and P. Mariani. 1994. The role of milk casein content in the Parmigiano-Reggiano cheese production: chemical composition, rennet coagulation properties and dairy technological behaviour of milk. Sci. Tecn. Latt. Cas. 45:519-535.

Fustini, M., A. Palmonari, G. Canestrari, E. Bonfante, L. M. E. Mammi, M. T. Pacchioli, G. C. J. Sniffen, R. J. Grant, K. W. Cotanch, and A. Formigoni. 2017. Effect of undigested neutral detergent fiber content of alfalfa hay on lactating dairy cows: Feeding behavior, fiber digestibility, and lactation performance. J. Dairy Sci. 100:4475-4483. https://doi.org/10.3168/jds.2016-12266.

Gandra, J. R., F. P. Rennó, J. E. de Freitas Júnior, M. V. dos Santos, and A. P. C. de Araújo. 2010. Productive performance and milk protein fraction composition of dairy cows supplemented with sodium monensin. Rev. Bras. Zootec. 39:1810-1817.

Garavaldi, A., M. Zannoni, B. Giussani, S. Roncoroni, L. Galassi, and M. Turrini. 2010. Scheda sensoriale per il Parmigiano Reggiano: Scelta dei descrittori e messa a punto del profilo. Sci. Tecn. Latt. Cas. 61:367-369.

Gatti, M., B. Bottari, C. Lazzi, E. Neviani, and G. Mucchetti. 2014. Invited review: Microbial evolution in raw-milk, long-ripened cheeses produced using undefined natural whey starters. J. Dairy Sci. 97:573-591. https://doi.org/10.3168/jds.2013-7187. 
Goodrich, R. D., J. E. Garrett, D. R. Gast, M. A. Kirick, D. A. Larson, and J. C. Meiske. 1984. Influence of monensin on the performance of cattle. J. Anim. Sci. 58:1484-1498.

IDF. 2000. Whole milk: Determination of milk fat, protein and lactose content - guidance on the operation of mid-infrared instruments. IDF Standard 141C:2000. Int. Dairy Fed., Brussels, Belgium.

Ipharraguerre, I. R., and J. H. Clark. 2003. Usefulness of ionophores for lactating dairy cows: A review. Anim. Feed Sci. Technol. 106:39-57. https://doi.org/10.1016/S0377-8401(03)00065-8.

ISO. 1993. Sensory analysis. General guidance for the selection, training and monitoring of assessors. Part 1: Selected assessors. ISO 8586-1. International Organization for Standardization. Geneva, Switzerland.

ISO. 1994. Sensory analysis. General guidance for the selection, training and monitoring of assessors. Part 2: Experts. ISO 8586-2. International Organization for Standardization. Geneva, Switzerland.

ISO. 2004a. Cheese and processed cheese products. Determination of fat content. Gravimetric method (Reference method). ISO 1735. International Organization for Standardization. Geneva, Switzerland.

ISO. 2004b. Cheese and processed cheese. Determination of the total solids content (Reference method). ISO 5534. International Organization for Standardization. Geneva, Switzerland.

ISO. 2004c. Milk. Determination of urea content. Enzymatic method using difference in $\mathrm{pH}$ (Reference method). ISO 14637. International Organization for Standardization. Geneva, Switzerland.

ISO. 2006. Milk. Enumeration of somatic cells. Part 2: Guidance on the operation of fluoro-opto-electronic counters. ISO 13366-2. International Organization for Standardization. Geneva, Switzerland.

ISO. 2011. Cheese and processed cheese. Determination of the nitrogenous fractions. ISO 27871. International Organization for Standardization, Geneva, Switzerland.

ISO. 2013. Milk. Bacterial count: Protocol for the evaluation of alternative methods. ISO 16297. International Organization for Standardization. Geneva, Switzerland.

ISO. 2014. Milk and milk products. Determination of nitrogen content. Part 1: Kjeldahl principle and crude protein calculation. ISO 8968-1. International Organization for Standardization. Geneva, Switzerland.

Jenkins, T. C. 1993. Lipid metabolism in the rumen. J. Dairy Sci. $76: 3851-3863$.

Jenkins, T. C., V. Fellner, and R. K. McGuffey. 2003. Monensin by fat interactions on trans fatty acids in cultures of mixed ruminal microorganisms grown in continuous fermentors fed corn or barley. J. Dairy Sci. 86:324-330.

Kraggerud, H., J. P. Wold, M. Høy, and R. K. Abrahamsen. 2009. $\mathrm{X}$-ray images for the control of eye formation in cheese. Int. J Dairy Technol. 62:147-153. https://doi.org/10.1111/j.1471-0307 2009.00478.x.

Liu, K.-S. 1994. Preparation of fatty acid methyl esters for gas-chromatographic analysis of lipids in biological materials. J. Am. Oil Chem. Soc. 71:1179-1187.

Malacarne, M., A. Summer, E. Fossa, P. Formaggioni, P. Franceschi, M. Pecorari, and P. Mariani. 2006. Composition, coagulation properties and Parmigiano-Reggiano cheese yield of Italian Brown and Italian Friesian herd milks. J. Dairy Res. 73:171. https://doi.org/ 10.1017/S0022029905001688.

McArt, J. A. A., D. V. Nydam, and G. R. Oetzel. 2012. Epidemiology of subclinical ketosis in early lactation dairy cattle. J. Dairy Sci. 95:5056-5066. https://doi.org/10.3168/jds.2012-5443.

McArt, J. A. A., D. V. Nydam, and M. W. Overton. 2015. Hyperketonemia in early lactation dairy cattle: A deterministic estimate of component and total cost per case. J. Dairy Sci. 98:2043-2054. https://doi.org/10.3168/jds.2014-8740.

McCarthy, M. M., T. R. Overton, G. D. Mechor, D. E. Bauman, T. C. Jenkins, and D. V. Nydam. 2018. Short communication: Field study to investigate the associations between herd-level risk factors for milk fat depression and bulk tank milk fat percent in dairy herds feeding monensin. J. Dairy Sci. 101:3118-3125. https://doi .org/10.3168/jds.2017-13932.

Mertens, D. R. 2002. Gravimetric determination of amylase-treated neutral detergent fiber in feeds with refluxing in beakers or crucibles: Collaborative study. J. AOAC Int. 85:1217-1240.

Mordenti, A. L., N. Brogna, and A. Formigoni. 2017. Review: The link between feeding dairy cows and Parmigiano-Reggiano cheese production area. Prof. Anim. Sci. 33:520-529. https://doi.org/10 .15232 /pas.2016-01602.

Mordenti, A. L., N. Brogna, F. Merendi, G. Canestrari, M. Dall'Olio, G. Biagi, and A. Formigoni. 2015. Effect of feeding whole soybean and linseed on milk and Parmigiano-Reggiano cheese lipid fraction. Prog. Nutr. 17:220-230.

Mullins, C. R., L. K. Mamedova, M. J. Brouk, C. E. Moore, H. B. Green, K. L. Perfield, J. F. Smith, J. P. Harner, and B. J. Bradford. 2012. Effects of monensin on metabolic parameters, feeding behavior, and productivity of transition dairy cows. J. Dairy Sci. 95:1323-1336. https://doi.org/10.3168/jds.2011-4744.

Newbold, C. J., R. J. Wallace, and N. D. Walker. 1993. The effect of tetronasin and monensin on fermentation, microbial numbers and the development of ionophore-resistant bacteria in the rumen. J. Appl. Bacteriol. 75:129-134.

OCQPR. 2015. Scheda per la valutazione sensoriale del ParmigianoReggiano in pezzi. Allegato 1 a Piano di controllo DOP Parmigiano Reggiano. Organismo Controllo Qualità Produzioni Regolamentate, Reggio Emilia, Italy. Accessed May 2018. http://www .ocqpr.it/images/documentazione/204---Scheda-sens.-formaggio -PR-in-pezzi---Allegato-3-PC---Rev.-04-06-18.pdf.

Odongo, N. E., M. M. Or-Rashid, R. Bagg, G. Vessie, P. Dick, E. Kebreab, J. France, and B. W. McBride. 2007. Long-term effects of feeding monensin on milk fatty acid composition in lactating dairy cows. J. Dairy Sci. 90:5126-5133. https://doi.org/10.3168/ jds.2007-0242.

Phipps, R. H., J. I. D. Wilkinson, L. J. Jonker, M. Tarrant, A. K Jones, and A. Hodge. 2000. Effect of monensin on milk production of Holstein-Friesian dairy cows. J. Dairy Sci. 83:2789-2794.

Piccioli Cappelli, F., M. G. Maianti, and G. Bertoni. 1996. Effect of Monensin supplementation on milk and metabolic characteristics of dairy cows. Pages 561-562 in Proceeding of SISVet Annual Conference, Perugia, Italy.

Prandini, A., S. Sigolo, G. Tansini, N. Brogna, and G. Piva. 2007. Different level of conjugated linoleic acid (CLA) in dairy products from Italy. J. Food Compos. Anal. 20:472-479. https://doi.org/10 $.1016 /$ j.jfca.2007.03.001

Ramanzin, M., L. Bailoni, S. Schiavon, and G. Bittante. 1997. Effect of monensin on milk production and efficiency of dairy cows fed two diets differing in forage to concentrate ratios. J. Dairy Sci. 80:1136-1142.

Reverberi, P., G. Gambini, A. Caroli, A. Pecorari, and M. Nocetti. 2009. Profilo dei siero-innesti per Parmigiano- Reggiano e modalità analitiche di valutazione. Sci. Tecn. Latt. Cas. 60:37-42. (Profile and analytical valuation of Parmigiano-Reggiano whey starters).

Rico, D. E., A. W. Holloway, and K. J. Harvatine. 2014. Effect of monensin on recovery from diet-induced milk fat depression. J. Dairy Sci. 97:2376-2386.

Russell, J. B., and H. J. Strobel. 1989. Effect of ionophores on ruminal fermentation. Appl. Environ. Microbiol. 55:1.

Sandri, S., F. Tosi, M. S. Mariani, P. Vecchia, M. Malacarne, and A. Summer. 2001. Osservazioni sull'andamento delle principali caratteristiche casearie del latte per Parmigiano-Reggiano durante gli anni 1990. Ann. Fac. Med. Vet. Univ. Parma 21:235-247.

Schmidt-Madsen, P. 1975. Fluoro-opto-electronic cell-counting on milk. J. Dairy Res. 42:227-239.

Sheehan, J. J. 2011. Cheese. Avoidance of Gas Blowing. Academic Press, San Diego, CA.

Sousa, M. J., Y. Ardö, and P. L. H. McSweeney. 2001. Advances in the study of proteolysis during cheese ripening. Int. Dairy J. 11:327345. https://doi.org/10.1016/S0958-6946(01)00062-0. 
Stoffel, W., F. Chu, and J. E. H. Ahrens. 1959. Analysis of long-chain fatty acids by gas-liquid chromatography. Anal. Chem. 31:307-308.

Suthar, V. S., J. Canelas-Raposo, A. Deniz, and W. Heuwieser. 2013. Prevalence of subclinical ketosis and relationships with postpartum diseases in European dairy cows. J. Dairy Sci. 96:2925-2938. https://doi.org/10.3168/jds.2012-6035.

Tosi, F., S. Sandri, G. Tedeschi, M. Malacarne, and E. Fossa. 2008 Variazioni di composizione e proprietà fisico-chimiche del Parmigiano-Reggiano durante la maturazione e in differenti zone della forma. Sci. Tecn. Latt. Cas. 59:507-528.

Trevisi, E., F. Piccioli Cappelli, M. Mezzetti, G. Lovotti, and P. Bani. 2015. Effect of the ruminal slow-release of monensin during the transition period of dairy cows on health status, energy metabolism and inflammatory conditions. Ital. J. Anim. Sci. 14:9.

Van der Werf, J. H. J., L. J. Jonker, and J. K. Oldenbroek. 1998. Effect of monensin on milk production by Holstein and Jersey cows. J. Dairy Sci. 81:427-433.
Van Nevel, C., and D. I. Demeyer. 1995. Lipolysis and biohydrogenation of soybean oil in the rumen in vitro: Inhibition by antimicrobials. J. Dairy Sci. 78:2797-2806. https://doi.org/10.3168/jds.S0022 -0302(95)76910-7.

Vanholder, T., J. Papen, R. Bemers, G. Vertenten, and A. C. B. Berge. 2015. Risk factors for subclinical and clinical ketosis and association with production parameters in dairy cows in the Netherlands. J. Dairy Sci. 98:880-888. https://doi.org/10.3168/jds.2014-8362.

Walstra, P., A. Noomen, and T. J. Geurts. 1978. Major Cheese Groups. Elsevier Applied Science, London, UK.

Wiggans, G. R., and G. E. Shook. 1987. A lactation measure of somatic cell count. J. Dairy Sci. 70:2666-2672.

Zannoni, M., and R. Mora. 1993. Evolution of the milk quality program for the Parmigiano-Reggiano cheese. Il Latte 18:572-581. 